DOI 10.37882/2223-2982.2021.07.32

\title{
НЕОЛОГИЗМЫ В СОВРЕМЕННОМ ИНГУШСКОМ ЯЗЫКЕ
}

\section{NEOLOGISTS IN THE MODERN INGUSH LANGUAGE}

M. Sultygova

P. Albakova

Summary: In recent decades, due to the development of science, culture, technology, and industry, the vocabulary of the Ingush language has changed, resulting in the appearance of new words and phrases that serve as names for new objects, phenomena, and concepts. Neologisms that have become units of the Ingush language are eventually included in dictionaries that reflect the current state of the vocabulary. The article deals with both the problems of modern neology and the issues related to the development and functioning of neologisms in the modern Ingush language.

Keywords: neology, neologisms, new words, modern Ingush language, development and functioning of neologisms.

\author{
Султыгова Марифа Магометовна \\ Д.фрилол.н., ФГБОУ ВО «Ингушский государственный \\ университет» \\ marifa_sultygiva@mail.ru \\ Албакова Пятимат Закрыевна \\ Aспирант, ФГБОУ «Ингушский государственный \\ университет»
}

Аннотация: В последние десятилетия в связи с развитием науки, культуры, техники, промышленности в словарном составе ингушского языка произошли изменения, выражающиеся в появлении новых слов и словосочетаний, служащих названиями новых предметов, явлений, понятий. Неологизмы, ставшие единицами ингушского языка, со временем входят в словари, отражающие актуальное состояние лексики. В статье рассматриваются как проблемы современной неологии, так и вопросы, связанные с освоением и функционированием неологизмов в современном ингушском языке.

Ключевые слова: неология, неологизмы, новые слова, современный ингушский язык, освоение и функционирование неологизмов.

кер, фрракци, префект, рейтинг, бизнесмен, мэр, фирма, лицензи, бартер, компьютер, ксерокс, принтер, Интернет, кикбоксинг, тэйквандо, экстрасенс, презентаци, спонсор, видео, гимнази, колледж, хиджаб и др.

б) Заимствования новых значений слов: ведущи - новое значение «ведущий программы, передачи, мероприятия»: бовзаш бола телеведущеш (известные телеведущие); отставка - слово приобрело значение «уход или смещение с правительственной должности»: отставке вахийта (отправить в отставку); субъект - новое значение слова «административно-территориальная единица»: федеральни субъект (субъект федерации).

Несмотря на неоднозначное отношение к иноязычной лексике, заимствование остается наиболее эффективным путем возникновения новых лексических единиц в ингушском языке. В этой связи важно разграничить заимствования, связанные с торговыми, экономическими, культурными и иными связями ингушей с разными народами, от собственно языкового заимствования, обусловленного необходимостью замены исконного многокомпонентного описательного наименования простым и однословным заимствованным термином [2, с. 146].

2. Калькированная лексика:

а) Словообразовательные кальки: бакьолораеш йола юкъарло (правозащитное общество), дуненюкъара теркамхой (международные наблюдатели), юкьарлонна хетарг (общественное мнение), тока laд (электрическая дуга), ахбекъам (полураспад),

1. Заимствования.

а) Новые слова и словосочетания: президент, спи- 
дега йоазо (кардиограмма);

б) Семантические кальки: хий дестар (разлив реки), молха тика (аптека), дарбадар (терапия), ювлар / эккхар (заряд);

в) Полукальки: ополчени (ополчение), mleмaн oneраци (военная операция), юкъара палата (общественная палата), сотови зыы (сотовая связь), граждански юкъарал (гражданское общество);

г) описательные конструкции - перевод иноязычного слова / понятия сочетанием двух и более слов: вичлуш дола иамгар/лазар (склероз), молха язбяр (рецепт), худдар хьалххе белгалдаккхар (прогноз), нормай боарам (нормативы);

д) неадекватные лексические новообразования, которые передают значение переводимого заимствования неточно или слишком обобщенно: гуманитарни ийче (гуманитарный коридор) слово ийче является буквальным переводом слова коридор; дегамолха (валериана, валидол) - букв, для сердца лекарство; лорий тоаба (медперсонал) букв, врачей группа; бустам (эталон) - выкройка, лекало; сурт даккхара искусство (фотоискусство) - слово сурт означает «фотография», «картина», «рисунок», «портрет», «образ».

3. Новая лексика, возникшая на основе исконного материала. Преобладающее ее большинство образовано при помощи суффиксов и являются именами существительными. Наиболее активно используются суффиксы -лла, -м, -р: листалла (частота) - листа (частый), хьекхам (трение) - хьакха (тереть), кхехкам (отвар) - кхехка (вариться).

Следует отметить новый способ присоединения суффикса отглагольных существительных - $p$, -л к основам существительного и прилагательного: говзал (мастерство) - говза (искусный), хувцам (обмен) - хувцар (менять), куцалг (украшение) - куи (внешний вид), сихдарг (ускоритель) - сихде (торопить), даимат (постоянная) - даиман (постоянный).

Значительное место при образовании новых слов занимает словосложение. Часть сложных слов представляет собой переосмысление значений русских слов и словосочетаний: гаьнасурт (перспектива) - гаьна (далеко) + сурт (вид, картина), б1аьргтохар (обзор) - б1аьрг (глаз) + mохар (букв, удар).

б) Семантическое развитие. Развитие значения происходит как у ингушских слов, так и у активно употребляемых заимствований, причем семантическое развитие заимствования происходит в родном языке. Например: тарелка (спутниковая антенна), сеть (мобильная сеть, компьютерная сеть), трубка (мобильный телефон), почта (электронная почта), фильтрационни (фильтра- ционный пункт), контрактник (служащий в военных подразделениях по контракту), помощь (гуманитарная помощь). Семантическое развитие большинства слов происходит под воздействием русского языка, чаще всего при терминологизации: хьажар - наблюдение, чухоам - пространство, гойтам - выражение.

4. Авторские неологизмы. В последние годы в ингушском языке наблюдается всплеск индивидуального словотворчества, что является одной из характерных черт ингушского языка на современном этапе. Причины этого явления носят в большей степени экстралингвистический характер, чем собственно-языковой. Явление словотворчества и его активность вызваны стремлением поднять престиж ингушского языка, попытками расширить его словообразовательные и функциональные возможности, что соответствует тенденциям пуризма в ингушском обществе данного периода.

Структура и семантика авторских неологизмов относительно прозрачна: бензин дотта меттиг (заправка), юхаоаз (эхо), фортали (шарф, повязывающийся на шею; по аналогии с кортали «повязывающийся на голове).

5. Активизация архаической лексики. Слова этой группы нельзя назвать неологизмами в полном смысле этого слова. Практически все слова являются заимствованиями из восточных языков, пришедшими в ингушский язык в различные периоды его развития. В советский период их заменили русские заимствования, и данная лексика перешла в пассивный словарь языка. Например: луг 1 am (словарь), шахьар (город), аийла (центр), ваххабит, хиджаб, халяль, миск, сивак.

Анализ исследуемой лексики позволил нам установить следующие основные тематические группы, в которые происходит активное вхождение новой лексики:

1. Общественно-политическая лексика. Данная группа представляет собой прямые заимствования из русского языка или посредством него, различные кальки и полукальки: президент, премьер-министр, мэри, префектура, брифинг, Пачхьалкхан Дума (Государственная Дума), Кхерамзале кхетарче (Совет Безопасности), МЧС, юкъаралена фонд (общественный фонд), рейтинг, имидж, гимнази, колледж, бакъоненна бух (правовая основа), федеральни округ, сага бакьонаш (права человека).

2. Экономическая лексика, которая представлена, главным образом, прямыми заимствованиями и множеством полукалек: бизнес, инфляци. инвестор, маркетинг, менеджер, приватизаци, юккъера бизнес (средний бизнес), лизингови система, оптови мах (оптовая цена), бизнес лелаер (заниматься бизнесом), фирма йилла (основать фирму), аренде эиа (взять в аренду). 
3. Военная лексика. Для данной группы слов характерны как заимствования, так и различные кальки: контрактник, федеральни эскар (федеральная армия), боевик, контртеррористически операци, спецназ, блокпост, зачистка, теман акци (военная акция), гуманитарни коридор, эскар арадаккхар (вывод войск), теракт.

4. Религиозная лексика. Эта группа слов относится к активизированной лексике (преимущественно заимствованной из арабского языка), что является ее характерной особенностью. В 90-е годы в активное употребление вошли слова: моджахед (воин, воюющий за веру), шахlид (воин, погибший в борьбе за веру), джихІад (в значении «война с неверными»), джамаlam (в значении «религиозная военизированная община»), джамаlama эмир (руководитель общины). Современными заимствованиями являются также слова: ваххабизм (название течения, противоречащего традиционному Исламу), ваххабит (сторонник ваххабизма), миск (ароматические масла, эссенции, привозимые из арабских стран), халяль (мясные продукты, дозволенные в употребление мусульманину), сивак (деревянная палочка для чистки зубов).

5. Медицина и спорт. Лексика этой группы немногочисленна и представляет собой заимствования из русского языка или посредством него из других языков. Отсутствие калек в медицинской и спортивной лексике объясняется ее интернациональным характером: одноразови иприи, контактни лннзаш, УзИ, томограф, пластически операци, компьютерни диагностика, экстрасенс, фитнес, каратэ, кикбоксинг, армрестлинг, тренажер, спортивни клуб.

6. Духовная и материальная культура. Данная группа объединяет в себе несколько тематических подгрупп: - сфера культуры, искусства, СМИ: массмедиа, шоу, имидж, дизайн, видеофильм, телесериал, пресс-релиз, модельер; - технологические новшества и названия бытовой техники, канцелярских принадлежностей: компьютер, программист, Интернет, ксерокс, принтер, дискета, факс, плейер, DVD, компакт-диск, музыкальни центр, кондиционер, миксер, органайзер, степлер, скотч; - названия одежды, обуви, аксессуаров: кроссовкаш (кроссовки), мокасинаш (мокасины), манто, mon, бейсболка, заколка (для волос), бижутери, портмоне; - еда и напитки: хот-дог, гамбургер, пичча, круассан, кетчуп, йогурт, чипсаш (чипсы), пепси-кола, кока-кола, зелени чай; - ономастика: Линда, Раяна, Ясмина, Ромина и др.

7. Терминология. Отличительная черта данной груп- пы - преобладание калькированных слов и выражений. Новая терминологическая лексика относится к различным отраслям знаний и видам деятельности:

а) лингвистические (фонетические) термины: алапий гойтам (буквенное выражение), артикуляционни оамал (артикуляционная характеристика), фонетически единицаш (фонетические единицы), хувцалуш йоаца белгалонаш (конститутивные признаки);

б) термины по математике, природоведению, физической культуре для школьного образования: арифметикан хъисапаш (арифметические действия), чlоаг1деш йола упражненеш (упражнения для закрепления), дагахь лархар (устное вычисление); 1алам лорадар (сохранение экологии), лаьттан бурилг (земной шар), яьсса аре (пустыня), нормай боарамаш (нормативы), кроссови кечам (кроссовая подготовка), духьалонаш эшаер (преодоление препятствий);

в) физические термины: мискхалг (частица), зарpam (ядро), хувцам боаца ток (постоянный ток);

г) медицинские термины: иlий лела маьженаш (органы кровообращения), дегайоазув (кардиограмма), вичлуш дола цамгар (склероз), баьци дарба (фитотерапия), синдарбанхо (психотерапевт);

д) термины эстетики: дизайн, аура, авторалли, ший тайпара халар (оригинальность), дестор (гротеск), турпал (герой);

е) философская терминология: хила дезар (необходимость), юхьса (дух), дер-лелор (деятельность), син маьршо (свобода духа / духовная свобода), вахаран маlан (смысл жизни), менталитет, фаталист, экзистениионализм.

Тематическая классификация новых слов и значений позволяет выявить активно изменяющиеся сферы общественной жизни, указывает на основные интересы и приоритеты в деятельности общества. В некоторой степени тематическая классификация может указать направления функционального развития языка, поскольку, наряду с заимствованием новой лексики, ингушский язык достаточно активно использует собственные словообразовательные возможности.

Следует подчеркнуть, что именно в эпоху коренных преобразований в языке появляется наибольшее количество новых слов и значений. Высокий уровень неологизации словаря является характерной чертой ингушского языка на современном этапе его развития. 


\section{ЛИТЕРАТУРА}

1. Брагина А.А. Неологизмы в русском языке: Пособие для студентов и учителей. -М.: Просвещение, 1973. -224 с.

2. Султыгова М.М. Сельскохозяйственная лексика ингушского языка. -Махачкала: АЛЕФ, 2017. - 256 с.

3. Брагина А.А. Неологизмы в русском языке: Пособие для студентов и учителей. -М.: Просвещение, 1973. -224 с.

4. Султыгова М.М. Сельскохозяйственная лексика ингушского языка. -Махачкала: АЛЕФ, 2017. - 256 с.

5. Попова Т.В. Русская неология и неография. -Екатеринбург: Угту-упи, 2005. -96 с.

○ Султыгова Марифа Магометовна (marifa_sultygiva@mail.ru), Албакова Пятимат Закрыевна.

Журнал «Современная наука: актуальные проблемы теории и практики»

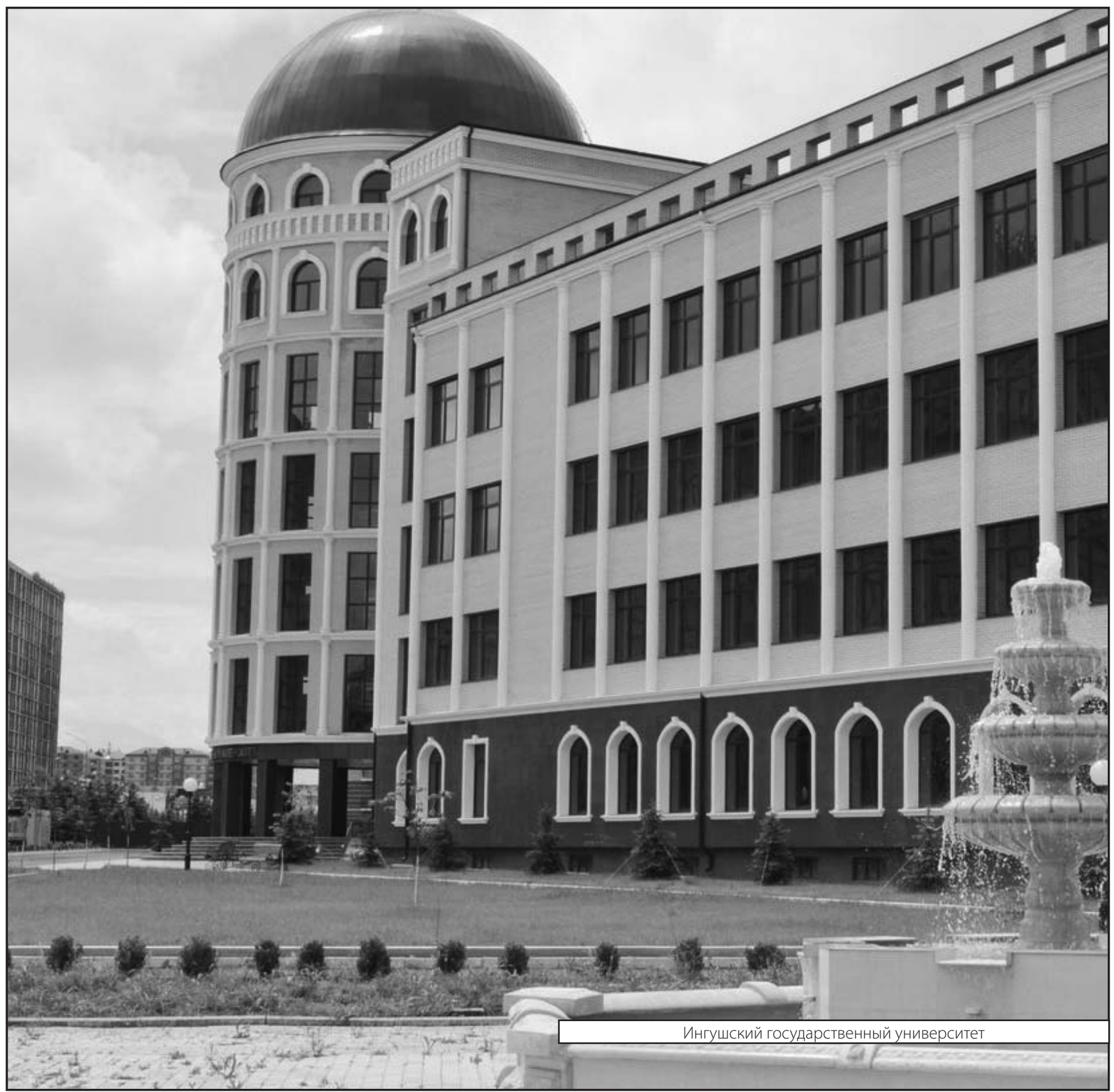

